\title{
SEXUAL POLYPLOIDIZATION IN RED CLOVER
}

\author{
Carine Simioni; Maria Teresa Schifino-Wittmann*; Miguel Dall'Agnol \\ UFRGS/FA - Depto. de Plantas Forrageiras e Agrometeorologia, C.P. 15100 - 91501-970 - Porto Alegre, RS - \\ Brasil. \\ *Corresponding author <mtschif@ufrgs.br>
}

\begin{abstract}
Because sexual polyploidization broadens genetic basis and supply plant breeders with more variability for the selection process, it can be useful in red clover breeding. This paper reports results of three crossing cycles, starting from a parental generation of tetraploid red clover plants (female parent), and diploids from the Quiñiqueli cultivar, selected for production of more than $1 \%$ of giant pollen grains (male parent) aiming to obtain tetraploid plants to be used in red clover breeding programs. Crosses in the next generations were performed by mutual cross-pollinations. Chromosome number chimerism and high pollen sterility were detected in $\mathrm{F}_{1}, \mathrm{~F}_{2}$ and $\mathrm{F}_{3}$, but there was a trend towards increasing seed production and seed viability along the generations, probably due to successful competition between fertile and sterile gametes. The identification of fertile triploids, as well as their recurrent formation along the generations, indicates that triploid block is not complete in red clover, and that triploids may be successfully used as a bridge for the production of sexual polyploids.
\end{abstract}

Key words: Trifolium pratense, plant breeding, triploid bridge, unreduced gametes

\section{POLIPLOIDIZAÇÃO SEXUAL EM TREVO VERMELHO}

\begin{abstract}
RESUMO: Porque a poliploidização sexual amplia a base genética e proporciona aos melhoristas maior variabilidade para o processo de seleção, ela pode ser uma ferramenta útil ao melhoramento de trevo vermelho. Com o objetivo de obter plantas tetraplóides que possam ser utilizadas em programas de melhoramento de trevo vermelho, este trabalho relata resultados de três ciclos de cruzamentos, partindo de uma população parental de plantas tetraplóides de trevo vermelho, como genitores femininos, e de diplóides da cultivar Quiñiqueli, selecionados para produção de mais de 1\% de grãos de pólen gigantes, como genitores masculinos. Nas outras gerações, os cruzamentos foram realizados por polinizações cruzadas mútuas. Quimerismo para número cromossômico e alta esterilidade de pólen foram detectados em $\mathrm{F}_{1}, \mathrm{~F}_{2}$ e $\mathrm{F}_{3}$, mas houve uma tendência para aumento da produção e viabilidade das sementes ao longo das gerações, provavelmente devido à competição bem sucedida entre gametas férteis e estéreis. A identificação de triplóides férteis, assim como sua formação recorrente ao longo das gerações, indica que o bloco triplóide não é completo em trevo vermelho e que triplóides podem ser utilizados com sucesso para a produção de poliplóides sexuais.

Palavras-chave: Trifolium pratense, gametas não-reduzidos, melhoramento de plantas, ponte triplóide
\end{abstract}

\section{INTRODUCTION}

Polyploidy is recognized as a major mechanism in plant evolution and adaptation (Ramsey \& Schemske, 1998; Bennett, 2004). Nearly $80 \%$ of the angiosperms are polyploids or have a polyploid origin (Leitch \& Bennett, 1997). From a plant breeding point of view, induction of polyploidy may originate new genetic combinations, providing the breeder with more variability.

In nature, most if not all polyploids have arisen by sexual polyploidization through unreduced (2n) gametes (De Wet, 1982; Ramanna, 1992; Ramsey \& Schemske, 1998), which production is genetically controlled (Bretagnolle \& Thompson, 1995) and have been reported in cultivated plants such as Alstroemeria (Ramanna et al., 2003), potato (Peloquin et al., 1992;
Ramanna \& Jacobsen, 1992), sweet potato (LopezLavalle \& Orjeda, 2002), alfalfa (Vorsa \& Bingham, 1979; McCoy \& Smith, 1983; Mariani et al., 1992; Barcaccia et al., 2003), ryegrass (Wagenvoort \& Den Nijs, 1992), white clover (Hussain \& Williams, 1997), red clover (Parrott \& Smith, 1984; 1986; Parrott et al., 1985; Mousset-Déclas et al., 1992, Simioni et al., 2004), Rosa hybrida (Crespel \& Gudin, 2003), among others.

In plant breeding, somatic polyploidization is still an important tool (Elliot, 1967; Taylor et al., 1976; Taylor \& Quesenberry, 1996). However, sexual polyploids are gaining increasing importance (Ramanna \& Jacobsen, 2003). Alfalfa sexual polyploids are more productive than somatic ones (McCoy \& Rowe, 1986). In potato (Carputo $\&$ Barone, 2005) and alfalfa (Sledge et al., 2002) they are used to transfer desirable characteristics from the wild into the cultivated species. 
The diploid $(2 \mathrm{n}=14)$ allogamous species red clover (Trifolium pratense L.) is a high quality forage legume, commonly grown in cultivated pastures of temperate regions (Taylor \& Quesenberry, 1996). In some parts of Rio Grande do Sul (ca. $33^{\circ}$ to $27^{\circ} \mathrm{S}$ ), it could be successfully grown if more persistent plants were selected (Montardo et al., 2003). Red clover somatic tetraploids are more persistent than diploids in some European regions (Taylor \& Quesenberry, 1996). Sexual polyploids could produce plants more persistent that would, at the same time, maintain high levels of heterozigozity. Results of three crossing cycles are herein reported, starting from a parental generation of induced tetraploids and diploids from cultivar Quiñiqueli to obtain sexual polyploids.

\section{MATERIAL AND METHODS}

\section{Plant materials and cytological determinations}

Seeds from tetraploid red clover plants derived from $2 \mathrm{x}-4 \mathrm{x}$ and $4 \mathrm{x}-2 \mathrm{x}$ crosses were kindly provided by Dr. Norman Taylor, University of Kentucky. After confirming the chromosome number of $2 n=28$ of the 27 adult plants obtained, 21 flowered plants were used as female parents in the crosses with 45 diploid Quiñiqueli plants (Figure 1). From a total of 226 adult plants from the diploid cultivar Quiñiqueli, those which formed more than $1 \%$ of giant pollen grains were selected to be used as male parents. Giant pollen grains (GP) were considered those 30 to $40 \%$ bigger than normal grains. According to the literature, pollen grains this size are assumed to be unreduced (Hermsen, 1984;

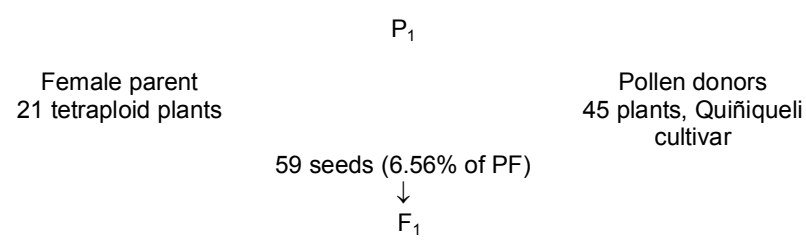

59 seeds $\rightarrow 48$ germinated $\rightarrow 17$ adult plants $\rightarrow 6$ flowered $\rightarrow$ 6 intercrossed $\rightarrow 32$ seeds $(21.68 \%$ of PF)

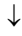

$\mathrm{F}_{2}$

32 seeds $\rightarrow 32$ germinated $\rightarrow 15$ adult plants $\rightarrow 5$ flowered $\rightarrow$ 2 intercrossed $\rightarrow 26$ seeds $(83.87 \%$ of PF)

$\downarrow$

$\mathrm{F}_{3}$

26 seeds $\rightarrow 25$ germinated $\rightarrow 13$ adult plants $\rightarrow$ 5 intercrossed $\rightarrow 145$ seeds $(55.13 \%$ of $P F)$

Figure 1 - Outline of the experimental crosses in red clover (details in the text). PF- number of pollinated flowers.
Ramanna, 1992). Pollen grain size is considered to be a reliable method to estimate unreduced gametes production in red clover (Parrott \& Smith, 1984; Simioni et al., 2004). Additionally, pollen grain size was measured in 30 grains from each of the tetraploid plants, and these measurements used as standard to classify the pollen grains of the Quiñiqueli plants. A total of 1,500 pollen grains, from different inflorescences, from each diploid plant, were examined and visually classified by size.

To check the ploidy level, root-tip chromosome number determinations were made in at least 10 cells per plant. Young roots were detached from the plants, pre-treated with paradichlorobenzene for $18-20 \mathrm{~h}$ at $4^{\circ} \mathrm{C}$ and fixed in 3:1 ethanol: acetic acid for $24 \mathrm{~h}$. Slides were prepared by staining the root-tips with Feulgen and squashing in $45 \%$ acetic acid. Estimation of pollen grain fertility was performed in 500 grains per plant, in all plants of all generations, by staining with propionic carmine. Pollen grains were considered fertile when full and well stained, while those unstained or weakly stained, were considered sterile (not viable).

\section{Crosses and selection cycles}

The experiment consisted in three crossing cycles, involving four generations: $\mathrm{P}_{1}, \mathrm{~F}_{1}, \mathrm{~F}_{2}$ and $\mathrm{F}_{3}$ (Figure 1). The first crosses were made by hand-pollinating 21 tetraploid plants with pollen from the selected Quiñiqueli plants with the aid of a small folded card. Adult plants (first generation) grown from seeds produced by this first cross, were mutually cross-pollinated and gave rise to seeds representing the second generation. Similarly, adult plants grown from these seeds were then intercrossed and gave rise to the third generation. Seeds were collected at least 21 days after pollinations, following recommendations of Taylor \& Smith (1979). During all the experimental period, plants were kept in pots in a greenhouse with a controlled photoperiod of $16 \mathrm{~h}$ light.

\section{RESULTS AND DISCUSSION}

\section{Parental generation}

All the female parent plants were tetraploid. Small degrees of chromosome number chimerism were observed in these plants, but the absolute majority of the root-tip cells had $2 \mathrm{n}=28$, confirming that all plants were tetraploid. Pollen grain size in these tetraploid parental plants was, in average, $64.0 \mu \mathrm{m}$ and $62.2 \mu \mathrm{m}$, considering the bigger and the smaller axis, respectively.

The general average of GP production among the 226 Quiñiqueli plants was $0.59 \%$, ranging from $0 \%$ 
to $9.07 \%$. Those plants which produced more than $1 \%$ of GP (average of $2.02 \%$, ranging from 1 to $9.07 \%$ ) were selected to be the male progenitors of the next generation. GP size in these plants was, in average, $65.5 \mu \mathrm{m}$ and $62.3 \mu \mathrm{m}$ (bigger and smaller axis), ranging from $61.2-70.7 \mu \mathrm{m}$ and 55.6-65.5 $\mu \mathrm{m}$, respectively. These measures were similar to the pollen grain size of the $\mathrm{P}_{1}$ tetraploid plants, therefore indicating that the visual identification of GP in diploid plants was a reliable parameter to select possible unreduced gametes.

A total of 900 flowers from the 21 tetraploid plants were pollinated with the 45 Quiñiqueli plants pollen. These crosses gave rise to $59 \mathrm{~F}_{1}$ seed $(6.55 \%$ of the pollinated $\mathrm{P}_{1}$ flowers produced seed) (Figure 1).

\section{$F_{1}$ generation}

From the 59 seeds produced in the previous generation, 48 germinated (81.35\% viability) and 17 plants survived. It was possible to determine the chromosome number in 11 plants; three were tetraploid $(2 n$ $=4 \mathrm{x}=28)$, and eight were triploid $(2 \mathrm{n}=3 \mathrm{x}=21)$, with varying degrees of chimerism. GP percentage ranged from 4.40 to $40.27 \%$ (average of $21.62 \%$ ) and pollen sterility varied from 16.86 to $52.73 \%$ (average of $33.79 \%$ ) (Table 1). A total of 143 flowers from seven of these plants were mutually pollinated and gave rise to $32 \mathrm{~F}_{2}$ seeds $\left(21.68 \%\right.$ of the pollinated $\mathrm{F}_{1}$ flowers produced seed) (Figure 1).

Table 1 - Chromosome number, percentage of giant pollen grains (GP) and percentage of sterile pollen grains in $\mathrm{F}_{1}$ plants

\begin{tabular}{lccc}
\hline Plant & $\begin{array}{c}\text { Chromosome } \\
\text { number }\end{array}$ & $\begin{array}{c}\text { GP } \\
\text { percentage }\end{array}$ & $\begin{array}{c}\text { Sterile grains } \\
\text { percentage }\end{array}$ \\
\hline $1 *$ & $28(?)$ & 40.27 & 16.86 \\
2 & 21 & 14.73 & 47.00 \\
3 & 28 & - & - \\
$4 *$ & 21 & 32.73 & 28.74 \\
5 & 28 & 34.60 & 25.27 \\
6 & 21 & - & - \\
$7 *$ & - & 14.67 & 31.13 \\
8 & 28 & - & - \\
9 & 21 & - & - \\
$10 *$ & 21 & 38.47 & 19.66 \\
$11 *$ & 21 & 4.40 & 52.73 \\
$12 *$ & - & 13.53 & 21.80 \\
$13 *$ & - & 9.88 & 35.72 \\
14 & 21 & 19.33 & 58.94 \\
\hline 15 & $21(?)$ & - & - \\
\hline 16 & - & - & - \\
17 & 21 & 15.20 & 33.80 \\
\hline Averages & & 21.62 & 33.79 \\
\hline
\end{tabular}

*plants that were intercrossed. ? uncertain.

\section{$F_{2}$ generation}

All of the $32 \mathrm{~F}_{2}$ seeds germinated and 15 plants survived, from which five flowered. Chromosome numbers could be verified with certainty in three plants: one was a triploid and the two others tetraploid. As a wide range of chromosome numbers were found among the root-tips of the other three plants, a reliable estimation of ploidy level was not possible. GP percentage ranged from 6.40 to $21.26 \%$ (average of $13.91 \%$ ) and pollen sterility was similar in the plants analyzed (from 28.60 to $29.47 \%$, with an average of $29.16 \%$ ) (Table 2). A total of 31 flowers were pollinated, which gave rise to $26 \mathrm{~F}_{3}$ seeds $(83.87 \%$ of the $\mathrm{F}_{2}$ pollinated flowers produced seed) (Figure 1).

\section{$F_{3}$ generation}

From those $26 \mathrm{~F}_{3}$ seeds, 25 germinated $(96.15 \%)$, and 13 reached the adult stage and flowered. Most of these plants had high percentages, sometimes over $50 \%$, of sterile pollen grains (Table 3 ). Due to a high incidence of chimerism, higher than in the former generations, it was not possible to determine with reasonable reliability the ploidy level of most of these plants, except five. However, as $2 \mathrm{n}=21$ was the most common number in the root-tip cells of all these plants, probably most of them were triploids. GP percentages ranged from 4.07 to $20.93 \%$ (average of $6.80 \%$ ), and percentage of pollen sterility ranged from 26.13 up to $77.60 \%$ (average of $45.05 \%$ ), the highest values of pollen sterility found in all generations evaluated (Table $3)$. A total of 263 flowers were pollinated and gave rise to $145 \mathrm{~F}_{4}$ seeds $\left(55.13 \%\right.$ of the pollinated $\mathrm{F}_{3}$ flowers produced seed), stored for future studies (Figure 1).

Considering all generations $\left(\mathrm{P}_{1}, \mathrm{~F}_{1}, \mathrm{~F}_{2}\right.$ and $\left.\mathrm{F}_{3}\right)$, the $\mathrm{F}_{1}, \mathrm{~F}_{2}$ and $\mathrm{F}_{3}$ plants were more chimeric regarding root-tip chromosome numbers than the original tetraploids (data not shown). Even considering the rather limited number of plants involved in the crosses, it was possible to detect not only a trend towards higher pollen sterility, but also to total, higher seed pro-

Table 2 - Chromosome number, percentage of giant pollen grains (GP) and percentage of sterile pollen grains in $\mathrm{F}_{2}$ plants.

\begin{tabular}{lccc}
\hline Plant & $\begin{array}{c}\text { Chromosome } \\
\text { number }\end{array}$ & $\begin{array}{c}\text { GP } \\
\text { percentage }\end{array}$ & $\begin{array}{c}\text { Sterile grains } \\
\text { percentage }\end{array}$ \\
\hline $\mathrm{a}^{*}$ & 21 & 6.40 & 28.60 \\
$\mathrm{~b}$ & 28 & - & - \\
$\mathrm{c}$ & 28 & 21.26 & 29.47 \\
$\mathrm{~d}$ & - & - & - \\
$\mathrm{e}^{*}$ & $?^{* *}$ & 14.07 & 29.40 \\
\hline Averages & & 13.91 & 29.16 \\
\hline
\end{tabular}

*plants that were intercrossed. **not possible to establish due to high chimerism. 
Table 3 - Chromosome number, percentage of giant pollen grains (GP) and percentage of sterile pollen grains in $\mathrm{F}_{3}$ plants.

\begin{tabular}{lccc}
\hline Plant & $\begin{array}{c}\text { Chromosome } \\
\text { number }\end{array}$ & $\begin{array}{c}\text { GP } \\
\text { percentage }\end{array}$ & $\begin{array}{c}\text { Sterile grains } \\
\text { percentage }\end{array}$ \\
\hline a1* & $?^{* *}$ & 20.93 & 30.60 \\
a2* & $?^{* *}$ & 8.73 & 26.13 \\
a3 & $?^{* *}$ & - & - \\
a4* & $?^{* *}$ & 12.20 & 39.47 \\
a5 & 21 & 4.27 & 51.73 \\
a6* & 21 & 9.20 & 77.60 \\
a7 & $?^{* *}$ & 6.80 & 33.40 \\
a8 & $?^{* *}$ & - & - \\
e1 & 21 & 4.93 & 74.67 \\
e2* & 21 & 8.07 & 36.53 \\
e3 & $? * *$ & - & - \\
e4 & ?* & - & - \\
e5 & 21 & 4.07 & 35.40 \\
\hline Averages & & 6.80 & 45.05 \\
\hline
\end{tabular}

*plants that were intercrossed. **not possible to establish due to high chimerism.

duction per plant (but not per pollinated flower) along the derived generations when compared to the parental generation (Figure 1, Tables 1, 2 and 3).

Production of GP in the initial population ranged from 0 to $9.07 \%$. Frequency of unreduced gametes production in non-hybrid plants is generally less than $1 \%$, and may vary among individuals (Veilleux, 1985; Ramsey \& Schemske, 1998, Lyrene et al., 2003). In the work of Parrott \& Smith (1984) for instance, 3\% of the diploid red clover plants analyzed produced more than 1\% GP (reaching up to $84 \%$ GP). Other authors also reported variable GP production, ranging from 4 to $37 \%$ in alfalfa (McCoy, 1982), and from 1 to $11 \%$ in Lotus tenuis (Negri, 1992). In this study, the range of variation in GP production in the initial population (0 to $9.07 \%$ ) was lower than those values cited above, but the percentage of individuals producing more than 1\% GP (19.91\%) was remarkably higher in comparison to the red clover population studied by Parrott \& Smith (1984). In this species, $2 n$ pollen is formed due to the occurrence of parallel or tripolar spindles during anaphase II (Parrot \& Smith, 1984).

As the size of GP produced by the selected Quiñiqueli plants, $\mathrm{F}_{1}, \mathrm{~F}_{2}$ and $\mathrm{F}_{3}$ plants was similar to the pollen grain size of the induced tetraploid $\mathrm{P}_{1}$ plants, it can be stated that the selection for unreduced gametes through pollen grain size was successful and biologically sound, supporting data from other authors (Hermsen, 1984; Parrott \& Smith, 1984; Ramanna, 1992) and our previous work with red clover (Simioni et al., 2004). In alfalfa, pollen grains formed by dip- loid plants and which had the same size of pollen grains from tetraploid plants were assumed to be unreduced (Mc Coy, 1982).

The tetraploid plants found in the $F_{1}$ generation (Table 1) were most probably formed by the union of unreduced pollen grains of the Quiñiqueli plants and the oospheres of the tetraploid female plants, while tetraploids in the following generations could be formed by three ways: union of normal gametes of the former generation tetraploid plants, or by the union of a tetraploid plant normal gamete and a $2 n$ gamete of a triploid plant, or by the union of two, $2 \mathrm{n}$ gametes of triploid plants. A break of the self-incompatibility system, allowing self-fertilization in tetraploid female plants, cannot be completely ruled out, as self-incompatibility systems may be broken down by polyploidy (Otto \& Whitton, 2000). However, as apparently no endogamic depression was observed in the derived plants, this possibility seems unlikely.

Interploidy crosses tend to be more successful when the tetraploid is the female parent, as was the case in the parental generation of the present work, as the endosperm-embryo balance will be more similar to the normal rule (Bretagnolle \& Thompson, 1995). It is ordinarily stated that triploid seeds are frequently aborted mainly due to endosperm-embryo unbalance (Ramsey \& Schemske, 1998; Beuselinck et al., 2003), and this post-zigotic reproductive barrier is called triploid block. That could explain the low percentage of seed formed in the first cross $(6.56 \%$ of the pollinated flowers produced seed) (Figure 1).

Working with red clover, Parrott \& Smith (1984) reported that tetraploid embryos resulting from $4 \mathrm{x}-2 \mathrm{x}$ crosses survived, but not the triploid ones, which led the authors to suggest that in this species the triploid block is very strong and, consequently, only tetraploid progeny is produced. However, our results lead to different conclusions.

Even considering that ploidy level was not ascertained in all plants, triploids were more frequent than tetraploids among $\mathrm{F}_{1}, \mathrm{~F}_{2}$ and $\mathrm{F}_{3}$ plants (Tables 1, 2,3 ), and seed production by pollinated flowers were higher in $\mathrm{F}_{1}, \mathrm{~F}_{2}$, and $\mathrm{F}_{3}$ crosses $(21.68 \%, 83.78 \%$, and $55.13 \%$, respectively) than in the original cross (Figure 1). The rather limited number of crosses performed should be kept in perspective. It could have affected the results, but reported data strongly suggests that the red clover populations used, have reasonable ability to tolerate different endosperm-embryo balances. Moreover, the high $\mathrm{F}_{1}, \mathrm{~F}_{2}$ and $\mathrm{F}_{3}$ seed germination $(81,35 \%$, $100 \%$, and $96.15 \%$, respectively), suggests that triploids are at least partially fertile. The fertility, or partial fertility of these triploids, not only allowed their reproduction but also their recurrent formation along 
the generations. According to Ramsey \& Schemske (1998), the barrier against triploids is not strong enough is some plants, probably because of some tolerance to varying endosperm balances, and this semifertility of triploids would allow them to generate new polyploids through the so called triploid bridge. Triploids may indeed facilitate tetraploid fixation by enhancing their rate of production (Husband, 2004). This seems to be the case in red clover. As fertility is a main requisite to allow gene transfer between different ploidy levels (Taylor \& Wiseman, 1987), our results suggest that in red clover triploids could be efficiently used as a bridge for interploidy gene transfer.

There was a tendency towards increasing chimerism in root-tip cells along the four generations. The chimerism in the root-tip cells as well as the high pollen sterility observed may be explained by disturbances in both somatic and meiotic divisions processes caused by polyploidy.

The four cycles were not enough to eliminate mixoploids, even possible aneuploids, from the population. Pollen fertility was also not improved, as percentages of sterile grains were still high from the second to the last generation analyzed. Similar results were found by Giri et al. (1983) in somatic tetraploids of red clover; percentage of aneuploids was similar and high even after six generations, what led the authors to suggest that selection for seed production may be more efficient than selection against aneuploids.

A tendency to higher seed productions along the generations could be observed. It could be suggested that the surviving plants, which were the parents of the next generation, were naturally selected for a higher meiotic stability and, consequently, produced more viable gametes. However, no steady decrease in the percentage of sterile grains was detected. Therefore, a higher competitive ability of the viable gametes, allied to a strong selection pressure at fertilization could explain the higher seed production efficiency in the later generations.

In conclusion, sexual polyploidization in red clover may be used as a tool to generate polyploids. Even with high chimerism and pollen sterility levels, viable seeds may be formed and give rise to triploid and tetraploid plants. Selection pressure should be towards seed production and not against pollen sterility or mixoploids, which may hinder, but not prevent, reproduction. Triploids in red clover are fertile enough to contribute with gametes to the next generation and are also recurrently formed in the population. Further work should aim at increasing the number of sexual polyploid plants and checking their agronomic performance in field trials.

\section{ACKNOWLEDGEMENTS}

The authors thank Dr. Norman Taylor, University of Kentucky, for the tetraploid seeds and Conselho Nacional de Desenvolvimento Científico e Tecnológico (CNPq, Brazil) and Financiadora de Estudos e Projetos (FINEP-Brazil) for financial support and for a $\mathrm{PhD}$ grant to the first author $(\mathrm{CNPq})$.

\section{REFERENCES}

BARCACCIA, G.; TAVOLETTI, S.; MARIANI, A.; VERONESI, F. Occurrence, inheritance and use of reproductive mutants in alfalfa improvement. Euphytica, v.133, p.37-56, 2003.

BENNETT, M.D. Perspectives on polyploidy in plants - ancient and neo. Biological Journal of the Linnean Society, v.82, p.411-423, 2004.

BEUSELINCK, P.R.; STEINER, J.J.; RIM, Y.M. Morphological comparison of progeny derived from $4 \mathrm{X}-2 \mathrm{X}$ and $4 \mathrm{X}-4 \mathrm{X}$ hybridizations of Lotus glaber Mill. and L. corniculatus L. Crop Science, v.43, p.1741-1746, 2003.

BRETAGNOLLE, F.; THOMPSON, J.D. Gametes with the somatic chromosome number: mechanisms of their formation and role in the evolution of autopoplyploid plants. New Phytologist, v.129, p.1-22, 1995.

CARPUTO, D.; BARONE, A. Ploidy level manipulations in potato through sexual hybridization. Annals of Applied Biology, v.146, p.71-79, 2005.

CRESPEL, L.; GUDIN, S. Evidence for the production of unreduced gametes by tetraploid Rosa hybrida L. Euphytica, v.133, p.65-69, 2003.

DE WET, J.M.J. Origins of polyploids. In: LEWIS, W.H. (Ed.) Polyploidy: biological relevance. New York: Plenum, 1982. p.3-15.

ELLIOT, F. Mejoramiento de plantas - citogenética. Mexico City: Compañia Editorial Continental, 1967. 476p.

GIRI, N.; TAYLOR, N.L.; COLLINS, G.B. Chromosome stability and fertility of a nitrous oxide-derived tetraploid population of red clover. Crop Science, v.43, p.45-48, 1983.

HERMSEN, J.G.T. Mechanisms and genetic implications of 2n-gamete formation. Iowa State Journal of Research, v.58, p.421-434, 1984.

HUSBAND, B.C. The role of triploid hybrids in the evolutionary dynamics of mixed-ploidy populations. Biological Journal of the Linnean Society, v.82, p.537-546, 2004.

HUSSAIN, S.W.; WILLIAMS, W.M. Evidence of functional gametes with unreduced chromosome number. Euphytica, v.97, p.21-24, 1997.

LEITCH, I.J.; BENNETT, M.D. Polyploidy in angiosperms. Trends in Plant Science, v.2, p.470-476, 1997.

LOPEZ-LAVALLE, L.A.; ORJEDA, G. Occurrence and cytological mechanism of $2 \mathrm{n}$ pollen formation in a tetraploid accession of Ipomoea batatas (sweet potato). Journal of Heredity, v.93, p.185$192,2002$.

LYRENE, P.M.; VORSA, N.; BALLINGTON, J.R. Polyploidy and sexual polyploidization in the genus Vaccinium. Euphytica, v.133, p.27-36, 2003.

MARIANI, A.; TAVOLETTI, S.; VERONESI, F. Alfalfa evolution and breeding through $2 \mathrm{n}$ gametes. In: MARIANI, A.; TAVOLETTI, S. (Ed.) Gametes with somatic chromosome number in the evolution and breeding of polyploid polysomic species: achievements and perspectives. Perugia: Forage Plant Breeding Institute, 1992. p.7381.

MCCOY, T.J. The inheritance of $2 \mathrm{n}$ pollen formation in diploid alfalfa Medicago sativa. Canadian Journal of Genetics and Cytology, v.24, p.315-323, 1982.

MCCOY, T.J.; ROWE, D.E. Single cross alfalfa (Medicago sativa L.) hybrids produced via $2 \mathrm{n}$ gametes and somatic chromosome doubling: experimental and theoretical comparisons. Theoretical and Applied Genetics, v.72, p.80-83, 1986. 
MCCOY, T.J.; SMITH, L.Y. Genetics, cytology, and crossing behavior of an alfalfa (Medicago sativa) mutant resulting in failure of the postmeiotic cytokinesis. Canadian Journal of Genetics and Cytology, v.25, p.390-397, 1983.

MONTARDO, D.P.; DALL'AGNOL, M.; PAIM, N.R. Forage yield and persistence of red clover progenies in two environments. Scientia Agricola, v.60, p.447-452, 2003.

MOUSSET-DÉCLAS, C.; COLAS, F.; TRONTIN, J.F. Variation in 2n production in red clover (Trifolium pratense $\mathrm{L}$.): effect of temperature and genotype. In: MARIANI, A.; TAVOLETTI, S. (Ed.) Gametes with somatic chromosome number in the evolution and breeding of polyploid polysomic species: achievements and perspectives. Perugia: Forage Plant Breeding Institute, 1992. p.61-65.

NEGRI, V. Frequency of big pollen occurrence in natural population of Lotus tenuis Wald et Kit. In: MARIANI, A.; TAVOLETTI, S. (Ed.) Gametes with somatic chromosome number in the evolution and breeding of polyploid polysomic species: achievements and perspectives. Perugia: Forage Plant Breeding Institute, 1992. p.5153.

OTTO, S.P.; WHITTON, J. Polyploid incidence and evolution. Annual Review of Genetics, v.34, p.401-437, 2000.

PARROTT, W.A.; SMITH, R.R. Production of $2 \mathrm{n}$ pollen in red clover. Crop Science, v.24, p.469-472, 1984.

PARROTT, W.A.; SMITH, R.R. Recurrent selection for diploid pollen formation in red clover. Crop Science, v.26, p.1132-1135, 1986.

PARROTT, W.A.; SMITH, R.R.; SMITH, M.M. Bilateral sexual tetraploidization in red clover. Canadian Journal of Genetics and Cytology, v.27, p.64-68, 1985.

PELOQUIN, S.J.; CHUOY, J.E.; WERNER, J.E. 4x hybrid progeny from $2 \mathrm{x}-2 \mathrm{x}$ crosses in potato. In: MARIANI, A.; TAVOLETTI, S. (Ed.) Gametes with somatic chromosome number in the evolution and breeding of polyploid polysomic species: achievements and perspectives. Perugia: Forage Plant Breeding Institute, 1992. p.2329.

RAMANNA, M.S. The use of $2 \mathrm{n}$ gametes in breeding polysomic polyploid species; some achievements and perspectives. In: MARIANI, A.; TAVOLETTI, S. (Ed.) Gametes with somatic chromosome number in the evolution and breeding of polyploid polysomic species: achievements and perspectives. Perugia: Forage Plant Breeding Institute, 1992. p.91-99.

RAMANNA, M.S.; JACOBSEN, E. Development of 2 n gamete producing diploid clones for breeding amylose-free potato. In: MARIANI, A.; TAVOLETTI, S. (Ed.) Gametes with somatic chromosome number in the evolution and breeding of polyploid polysomic species: achievements and perspectives. Perugia: Forage Plant Breeding Institute, 1992. p.39-44.
RAMANNA, M.S.; JACOBSEN, E. Relevance of sexual polyploidization for crop improvement - A review. Euphytica, v.133, p.3-18, 2003.

RAMANNA, M.S.; KUIPERS, A.G.J.; JACOBSEN, E. Occurrence of numerically unreduced (2n) gametes in Alstroemeria interspecific hybrids and their significance for sexual polyploidization. Euphytica, v.133, p.95-106, 2003.

RAMSEY, J.; SCHEMSKE, D.W. Pathways, mechanisms and rates of polyploid formation in flowering plants. Annual Review of Ecology and Systematics, v.98, p.467-501, 1998.

SIMIONI, C.; SCHIFINO-WITTMANN, M.T.; DALL'AGNOL, M.; GUERRA, D. Selection for increasing $2 \mathrm{n}$ gametes production in red clover. Crop Breeding and Applied Biotechnology, v.4, p.477-483, 2004.

SLEDGE, M.K.; BOUTON, J.H.; DALL'AGNOL, M.; PARROTT, W.A.; KOCHERT, G. Identification and confirmation of Aluminum tolerance QTL in diploid Medicago sativa subsp. coerulea. Crop Science, v.42, p.1121-1128, 2002.

TAYLOR, N.L.; SMITH, R.S. Red clover breeding and genetics. Advances in Agronomy, v.31, p.125-153, 1979.

TAYLOR, N.L.; WISEMAN, E.O. Triploids and tetraploids from 4x-2x crosses in red clover. Crop Science, v.27, p.14-18, 1987.

TAYLOR, N.L.; QUESENBERRY, K.H. Red clover science. Dordrecht: Kluwer Academic, 1996. 226p.

TAYLOR, N.L.; ANDERSON, M.K.; QUESENBERRY, K.H.; WATSON, L. Doubling the chromosome number of Trifolium species using nitrous oxide. Crop Science, v.16, p.516-518, 1976.

VEILLEUX, R. Diploid and polyploid gametes in crop plants: mechanisms of formation and utilization in plant breeding. Plant Breeding Reviews, v.3, p.253-288, 1985.

VORSA, N.; BINGHAM, E.T. Cytology of $2 \mathrm{n}$ pollen formation in diploid alfalfa, Medicago sativa. Canadian Journal of Genetics and Cytology, v.21, p.525-530, 1979 .

WAGENVOORT, M.; DEN NIJS, A.P.M. Implications of $2 \mathrm{n}$ pollen for breeding tetraploid perennial ryegrass. In: MARIANI, A.; TAVOLETTI, S. (Ed.) Gametes with somatic chromosome number in the evolution and breeding of polyploid polysomic species: achievements and perspectives. Perugia: Forage Plant Breeding Institute, 1992. p.5-14.

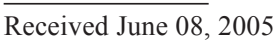

Accepted December 20, 2005 